\title{
無電解銅めっきの現状と将来
}

\author{
清 水悟* \\ *荏原ユージライト(株) 中央研究所 (†251-0876 神奈川県藤沢市善行坂 1-1-6)
}

\section{The Present and Future Trends in Electroless Copper Plating}

\author{
Satoru SHIMIZU*
}

*Central Res. Lab., Ebara Udylite Co., Ltd. (1-1-6, Zengyozaka, Fujisawa-shi, Kanagawa 251-0876)

Keywords : Electroless Copper Plating

\section{1.はじめに}

無電解銅めつきは，プリント配線板とプラスチックめつき への応用から工業的に広まり，さまざまな研究がなされてき た。しかし, 構成成分が多く作用機構が複雑なため, 未だ未 知な部分も多く, メカニズムについて完全に解明されてはい ない。本解説では, 無電解銅めっきの基本的な反応機構や用 途，今後の応用例について紹介する。

\section{2. 無電解銅めっきの歴史}

無電解銅めっきの起源は 1940 年代後半に, 銅塩とロッ シェル塩と水酸化ナトリウムからなるフェーリング夜にホル ムアルデヒドを添加し銅を還元する液が H. Narcus ${ }^{1)}$ や . $\mathrm{Wein}^{2)}$ により報告されているのが最初とされている。1950 年代にプリント配線板のスルーホールの導通化処理として応 用され盛んな研究成果が発表された ${ }^{3), 4)}$ 。R. M. Lukes ${ }^{5)}$ EDTA 浴でのホルムアルデヒドの酸化反応機構について, W. Goldie ${ }^{6)}$ はロッシェル塩浴の各成分がめっき速度に与え る影響について, 小西7) はロッシェル塩浴での反応機構と安 定剤の効果について報告している。また，この頃には装飾・ 機能用途として自動車や電気製品向けのプラスチック上の めっきとして応用され, 無電解銅めっきはより工業的に重要 な技術として確立された。

電気化学的な研究としては, 1965 年に斎藤 8 ,9) が無電解銅 めつきの各成分が局部アノード反応と局部カソード反応に与 える影響について研究し, 混成電位論を確立したのが始まり である。広幡ら ${ }^{10)}$ は安定剤の外部分極曲線への影響を, 大 野ら ${ }^{11,12)}$ は分極抵抗法によるめつき速度の推定法について 報告するなど, 電気化学的手法は無電解銅めっきの反応機構 の解明に有効に用いられている(13) 16)。

1970 年代からは, 厚付け無電解銅めっきの皮膜物性改善 のためにさまざまな報告がされている。広幡ら ${ }^{17)}$ は EDTA 浴での添加剤が皮膜延性と結晶性に与える影響について調査 し，第一銅イオンの錯化剤として働く化合物が延性を向上さ
せることを報告した。斎藤ら ${ }^{18)}$ は第一銅イオンの定量法の 確立により，ロッシェル塩浴では第一銅イオンの生成が多い が，EDTA やクワドロール๋浴では第一銅イオンが生成しな いことを確認し，これらの浴の添加剤が皮膜表面形状や延性 に与える影響について報告している。松岡ら ${ }^{19), 20)}$ は EDTA 浴とクワドロール浴における安定剤が延性や結晶粒径に与え る影響や溶存酸素の挙動について調查した。水本ら ${ }^{21), 22)}$ グリシンを添加したEDTA 浴の皮膜の機械的物性や熱処理 の影響について報告した。また最近の報告では $\mathrm{J}^{2} \mathrm{Li}^{23)} に よ$ る EDTA/TEA 錯体浴による無電解銅めつきの高速化の研 究などがあるが, 最近はめっき液の基礎的な研究例は少なく なっている。

\section{3. 無電解銅めっき浴の成分}

\section{1 ホルムアルデヒド浴}

無電解銅めっき浴の成分は銅塩, 還元剂, 錯化剂, $\mathrm{pH}$ 調 整剤, 添加剤から構成される。表 1 亿代表的な無電解銅めつ きの組成を示す9),26)。

銅塩には主に硫酸銅や塩化銅が用いられる。銅の標準電極 電位は+0.334 V と高いため, ホルムアルデヒドのような還 元力は弱いが酸化速度が速いものが還元剤として適してい る ${ }^{24)}$ 。そのため工業的に使用される浴はほとんどがホルムア ルデヒドを使用している。ホルムアルデヒドの酸化反応はア ルカリ溶液でしか起こらず, pH 12 以上の高アルカリ域で酸 化速度が高くなる ${ }^{25)}$

$\mathrm{pH}$ 調整剤には水酸化ナトリウムが使用され，またアルカ リ溶液中で銅を溶解させるためにロッシェル塩, EDTA, クワドロールなどの錯化剂が使用される。厚付け用途には 50〜 $70^{\circ} \mathrm{C}$ 高温で高速な無電解銅めっきが必要であり, 高温 で安定性が良いEDTA やクワドロールが適している。

添加剤としては, めっき液の液分解を防止するための安定

\footnotetext{
${ }^{\dagger} \mathrm{N}, \mathrm{N}, \mathrm{N}{ }^{\prime}, \mathrm{N}$ '-テトラキス$(2$-ヒドロキシプロピル)エチレンジアミ ン
} 
表 1 無電解銅めっき浴の組成例

\begin{tabular}{|c|c|c|}
\hline & ロッシェル塩浴(薄付け) & EDTA 浴(厚付け) \\
\hline 銅 塩 & $\mathrm{CuSO}_{4} \quad 0.04 \mathrm{M}$ & $\mathrm{CuSO}_{4} \quad 0.03 \mathrm{M}$ \\
\hline 錯化剈 & ロッシェル塩 $0.1 \mathrm{M}$ & EDTA $\quad 0.08 \mathrm{M}$ \\
\hline 還元剈 & $\mathrm{HCHO} \quad 0.4 \mathrm{M}$ & HCHO $\quad 0.33 \mathrm{M}$ \\
\hline pH 調整剤 & $\mathrm{NaOH} \quad$ pH 12.5 & $\mathrm{NaOH} \quad \mathrm{pH} 12.5$ \\
\hline 添加剤 & $\begin{array}{c}\text { 硫黄化合物 } \\
0.2 \mathrm{mg} / \mathrm{L} \\
\end{array}$ & $\begin{array}{c}2,2 \text { 'ビピリジル } 10 \mathrm{mg} / \mathrm{L} \\
\text { PEG-1000 } 250 \mathrm{mg} / \mathrm{L}\end{array}$ \\
\hline 浴 温 & $25^{\circ} \mathrm{C}$ & $50^{\circ} \mathrm{C}$ \\
\hline めっき速度 & $0.3 \mu \mathrm{m} / 15$ 分 & $2 \sim 3 \mu \mathrm{m} / \mathrm{h}$ \\
\hline
\end{tabular}

凨, 速度を促進する促進剤, 皮膜の機械的物性を改善する皮 膜改良剤，めつき液の表面張力を下げる界面活性剤などがあ り，これら添加剤の役割は非常に大きく無電解銅めっき液の 性能は添加剤によって決定されるといえる。安定剤の働きに は，第 1 銅イオンとの錯形成，金属銅表面への吸着，ホルム アルデヒド酸化を抑制する作用などがあり，これにより金属 銅粒子の析出と浴の自己分解が防止される。安定剤としては 無機シアン，2,2'-ビピリジルなどの窒素化合物やチオ尿 素・チオシアン酸などの硫黄化合物，水銀，五酸化バナジウ ムなどの無機化合物が単独あるいは複合して用いられる ${ }^{27)}$ 促進剤には，アンモニウム塩やモリブデン酸塩，タングステ

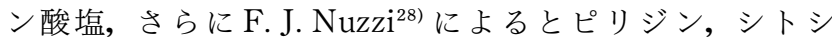
ン・グアニジン塩酸塩などに促進効果があると報告されてい る。皮膜改良剤・界面活性剤として，本間ら ${ }^{26)}$ はビピリジ ルを安定剤とする EDTA 浴にポリエチレングリコールを添 加することで皮膜中の水素含有量が減少し延性が向上するこ とを確認している。

\section{2 ホルムアルデヒドフリー浴}

現在，工業用に使用される無電解銅めっきはほとんどがホ ルムアルデヒドを還元剤として使用しているが，ホルムアル デヒドは臭気が強く人体への悪影響があるなど環境面で問題 がある。ホルムアルデヒドフリー化は以前から望まれている が，これに代わり得る還元剤がないためやむなく使用してい るのが実情である。ホルムアルデヒド以外の還元剤としては， グリオキシル酸, 次亜リン酸塩, DMAB，水素化ホウ素ナ トリウム，ヒドラジンなどが報告されているが，実用化され ている例は少ない。

グリオキシル酸はホルムアルデヒドの誘導体でありホルム アルデヒドと同様な作用機構で銅を還元することができるた め ${ }^{29)}$ ，ホルムアルデヒドの代替として多くの報告がされてい る。本間ら ${ }^{30)}$ は，グリオキシル酸浴はホルムアルデヒド浴 と比較して析出速度が速く皮膜の延性も良好でスルーホール 内の均一析出性が高いことを報告した。板橋ら ${ }^{31)}$ はこれら の性質を利用して厚付け無電解銅めっきへの応用を検討した。 しかしグリオキシル酸はホルムアルデヒドと比較してカニッ ツァロ反応による分解が速く，また副生成物であるシュウ酸 塩の溶解度が低く老化すると沈殿が生じるので浴寿命が短い のが欠点である。また原料価格もホルムアルデヒドの 5 倍以 上と高く実用化にはまだ課題が多い。

次亜リン酸を還元剂とする浴も多く検討されている。次亜

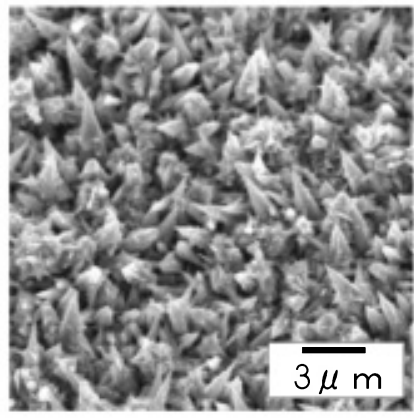

針状結晶

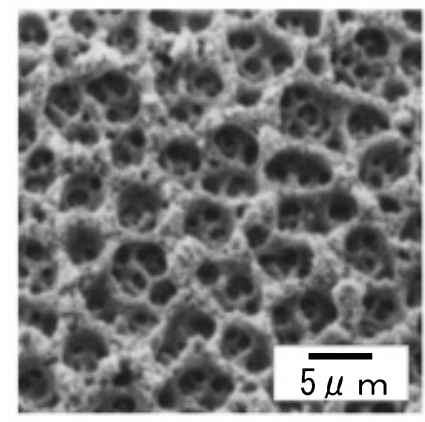

ポーラス状
図 1 次亜リン酸浴のめっき皮膜の表面形状

リン酸は，酸化電位が銅の還元電位と比較してかなり卑であ るため，容易に銅を還元するように思えるが，次亜リン酸に 対して銅の触媒活性度が低いため銅表面では次亜りン酸の酸 化反応が起こらず無電解銅めっきの還元剤としては不向きで ある ${ }^{12)}$ 。たとえばパラジウム触媒を付与した基材を次亜リン 酸浴でめっきしても，パラジウム上では銅の析出反応が開始 するが，表面が銅で覆われると活性度が低下し反応が停止し てしまう。これに対して A. Hung ${ }^{32)}$ はクエン酸を錯化㓮と する次亜リン酸浴に少量のニッケルを添加し銅ーニッケル合 金化することで，自己触媒性が現われ連続的にめっきが可能 であることを報告している。藤波ら ${ }^{33), 34)}$ はこの浴に添加剤 を加えると針状結晶やポーラス状の皮膜になる性質を利用し て, 多層プリント配線板の内層粗化処理として応用した(図 1 )。最近では J. Li ら ${ }^{35)}$ が, HEDTA を錯化剂とする次亜 リン酸浴にチオ尿素を添加することで, 速度が増加し, 皮膜 の電気抵抗值が低下することを報告している。

その他の還元剤として，DMAB，水素化ホウ素ナトリウ ム ${ }^{36)}$ ，ヒドラジン ${ }^{12)}$ などが検討されているが，これらは還 元力が強く液分解しやすい欠点があり実用化されていない。

最近では A. Vaskelis ら ${ }^{37)}$ が報告したコバルト(II)塩を還 元剂とする無電解銅めっきが注目されている。この浴は $\mathrm{Co}^{2+} \rightarrow \mathrm{Co}^{3+}+\mathrm{e}^{-}$の酸化反応を銅の還元に利用しており, 中 性域でめっき可能であること, 水素ガスの発生が無いことが 特徵である。M. Sone ら ${ }^{38)}$ はこれと同様の原理で $\mathrm{Fe}^{2+}$ を還 元剤とする浴で各種錯化剤の検討を行っている。これらの浴 は浴寿命が短く連続使用には難点があり, 今後の改良が期待 される。 


\section{4 . 無電解銅めっきの反応機構}

ホルムアルデヒドを還元剤とする無電解銅めつきの化学反 応式を示す9)。

主反応 $: \mathrm{Cu}^{2+}+2 \mathrm{HCHO}+4 \mathrm{OH}^{-}$

$$
\rightarrow \mathrm{Cu}^{0}+2 \mathrm{HCOO}^{-}+\mathrm{H}_{2} \uparrow+2 \mathrm{H}_{2} \mathrm{O}
$$

カソード反応: $\mathrm{Cu}^{2+}+2 \mathrm{e}^{-} \rightarrow \mathrm{Cu}^{0}$.

アノード反応：

$$
2 \mathrm{HCHO}+4 \mathrm{OH}^{-} \rightarrow 2 \mathrm{HCOO}^{-}+\mathrm{H}_{2} \uparrow+2 \mathrm{H}_{2} \mathrm{O}+\mathrm{e}^{-} \cdots(3)
$$$$
\mathrm{H} \cdot \rightarrow \mathrm{H}^{+}+\mathrm{e}^{-}
$$

副反応 :

$$
\begin{aligned}
& 2 \mathrm{HCHO}+\mathrm{OH}^{-} \rightarrow \mathrm{HCOO}^{-}+\mathrm{CH}_{3} \mathrm{OH} \\
& 2 \mathrm{Cu}^{2+}+\mathrm{HCHO}+5 \mathrm{OH}^{-} \rightarrow \mathrm{Cu}_{2} \mathrm{O}+\mathrm{HCOO}^{-}+3 \mathrm{H}_{2} \mathrm{O} \text { (6) } \\
& \mathrm{Cu}_{2} \mathrm{O}+2 \mathrm{HCHO}+2 \mathrm{OH}^{-} \\
& \rightarrow 2 \mathrm{Cu}^{0}+\mathrm{H}_{2} \uparrow+2 \mathrm{HCOO}^{-}+\mathrm{H}_{2} \mathrm{O} \\
& \mathrm{Cu}_{2} \mathrm{O}+\mathrm{H}_{2} \mathrm{O} \rightarrow \mathrm{Cu}^{0}+\mathrm{Cu}^{2+}+2 \mathrm{OH}^{-} \\
& \mathrm{Cu}_{2} \mathrm{O}+1 / 2 \mathrm{O}_{2}+2 \mathrm{H}_{2} \mathrm{O} \rightarrow 2 \mathrm{Cu}^{2+}+4 \mathrm{OH}^{-}
\end{aligned}
$$

主反応の他に, 副反応としてホルムアルデヒドの不均化反 応であるカニッツァロ反応(5)や $\mathrm{Cu}_{2} \mathrm{O}$ の生成(6), $\mathrm{Cu}_{2} \mathrm{O}$ の不 均化反応(8)がある。(3)式のホルムアルデヒドの酸化反応は $\mathrm{pH}$ が 12 以上で促進されるが, $\mathrm{pH} 12.5$ 以上では(5)式のカ ニッツァロ反応が優先する。そのため $\mathrm{pH}$ が高すぎるとめつ き速度が低下し, また浴中の溶存酸素も低下して $\mathrm{Cu}_{2} \mathrm{O}$ が生 成されやすくなり浴が不安定となる。無電解銅めっき浴はカ ニッツァロ反応により常にホルムアルデヒドとアルカリが消 費されるため, 濃度を保つには定期的な補給が必要である。

無電解銅めっきの浴分解は, (8)式の $\mathrm{Cu}_{2} \mathrm{O}$ の不均化反応で 金属銅粒子が析出することによって起こる。生成した $\mathrm{Cu}_{2} \mathrm{O}$ は(9)式に示すとおり酸素により $\mathrm{Cu}^{2+}$ に酸化される。そのた め常時空気を通気し溶存酸素濃度を高く保つことで浴分解を 防ぐことができる。 $\mathrm{Cu}_{2} \mathrm{O}$ の生成は錯化㓮によって異なり, $\mathrm{Cu}^{2+}$ との安定度定数が高い EDTA 浴では $\mathrm{Cu}_{2} \mathrm{O}$ の生成は非 常に少ないが，ロッシェル塩浴ではホルムアルデヒドが存在 しなくとも $\mathrm{Cu}_{2} \mathrm{O}$ が生成し ${ }^{20)}$ ，(9)式により溶存酸素が低下す る。そのためロッシェル塩浴は高温では安定性に欠け, 通常 は $30^{\circ} \mathrm{C}$ 前後の温度で使用される。溶存酸素濃度は過剩に高 くてもめっき液の活性度を低下するので，2～ $5 \mathrm{ppm} の$ 適 度な濃度に保つ必要がある。無電解銅めっきに安定剤として 使用される 2,2'-ビピリジルやシアン化合物は, $\mathrm{Cu}_{2} \mathrm{O}$ と錯体 を形成しトラップすることによりめつき浴の安定性を向上す る。

無電解銅めっきを連続使用すると(1)(5)式の反応によりギ酸
やメタノールが生成し, また銅塩とアルカリの補給により塩 類も蓄積するため, めっき液の比重は徐々に増加する。比重 の増加にともない溶存酸素濃度が低下し浴安定性が低下する ので液比重 1.1 程度が液の更新目安とされている。

\section{5. 無電解銅めっきの用途}

\section{1 プラスチックへのめっき}

プラスチックへの金属化処理「プラめっき」は，導電性の 付与，耐熱性・機械的性質の改善，金属質感の付与などの目 的で古くから行われており，自動車部品や家電製品の ABS 樹脂へのめつきとして普及した ${ }^{39) \sim 41)}$ 。プラスチックへの無 電解めっきで重要な点は樹脂との密着性であり, ABS 樹脂 へのめっきではクロム酸／硫酸のエッチング液で樹脂表面を 粗化する方法で密着が確保されている。密着性の向上には エッチング条件の他に樹脂の組成や成形条件も重要で，松永 $ら^{42)}$ は, これらの条件が密着強度に与える影響について調 查している。 $\mathrm{ABS}$ 樹脂の他にもさまざまなエンジニアリン グプラスチックへのめつきも可能であるが，それぞれの樹脂 に適したエッチング工程を選択する必要がある ${ }^{43)}$ 。プラめつ きには当初はコストが安い無電解銅めつきが多く使われてい たが, 密着性が無電解ニッケルと比較してやや劣ることやザ ラなどの不良が発生しやすい欠点があり最近では無電解ニッ ケルめっきが主流である。

電子機器の用途では電磁波を遮断するためのシールドとし て，プラスチック製ハウジングへ無電解銅めっきがされてい る。銅や銀が他の金属と比較してシールド特性に優れ，特に 銅はコストが安いので最適である。ただし銅は表面が酸化し やすい欠点があるので， 0.5〜 $1 \mu \mathrm{m}$ の無電解銅めっきの上 に更に置換により $\mathrm{Pd}$ 触媒を付与し $0.3 \mu \mathrm{m}$ 程度の無電解 ニッケルめつきを施すことが多い44)

\section{2 プリント配線板へのめつき}

5. 2. 1 薄付けスルーホールめつき

無電解銅めっきはプリント配線板のスルーホールの導電化 処理として実用化され, 急速な発展を遂げた。リジッド基板 の場合はエポキシ樹脂とガラス, フレキシブル基板の場合は ポリイミドが絶縁層として用いられているので，まず $0.3 \sim 0.5 \mu \mathrm{m}$ の薄付け無電解銅めっきでこれらの絶縁層上を 導電化処理し, 次いで $20 \mu \mathrm{m}$ 程度の電気銅めつきで厚膜化 する手法が一般的である。スルーホールめっき工程を表 2 に 示す。スルーホールめっきでは, ボイドなどの欠陥が無く均 一に無電解銅めつきを析出させることと基板の銅䈃と銅めつ き間の密着を確保することの二点が重要である。コンディ

表 2 プリント配線板用のスルーホールめつき工程

\begin{tabular}{cl}
\hline エ & \multicolumn{1}{c}{ 程 } \\
\hline クリーナー・コンディショナー & 脱脂・洗浄, $\mathrm{Pd}$ 吸着のための予備処理 \\
\hline ソフトエッチング & 銅䇴のエッチング処理 $($ 約 $1 \mu \mathrm{m})$ \\
\hline プレディップ & キャタライザー浴の成分濃度の安定化 \\
\hline キャタライザー & めっき開始のためのパラジウム触媒の付与 \\
\hline アクセレレーター & パラジウム触媒の金属化, $\mathrm{Sn}$ の除去と $\mathrm{Pd}^{2+}$ の還元 \\
\hline 無電解銅めっき & 電気銅めっきのための導電化処理 $(0.3 \sim 0.5 \mu \mathrm{m})$ \\
\hline
\end{tabular}


ショニング処理は，エポキシやガラス，ポリイミドなどのさ まざまな基材に対して適度に均一にPd触媒を吸着させるた めの前処理である。これは Pd 吸着が多ければ密着不良，少 なければ無めっきとなるためである。無電解銅めっき開始の 触媒には, $\mathrm{Pd} / \mathrm{Sn}$ の混合コロイドタイプかあるいはアルカ リ性の Pd イオン錯体タイプが用いられる。一般的なディッ プ方式ではコロイドタイプ, 水平搬送の装置ではイオンタイ プが使用される例が多い。

無電解銅めっきは低温で付きまわりが良いタイプが適して おり，主にロッシェル塩浴や EDTA 浴が使用される。ロッ シェル塩浴は錯化剤の分解性が良い利点があるが，安定剤に シアンを使用しないと安定性が低いという欠点もある。 EDTA 浴は錯化剤の分解性は悪いが, 析出開始が速く安定 性も良いことから，最近ではEDTA 浴が主流となっている。

5. 2. 2 厚付け無電解銅めっき

プリント配線板への厚付け無電解銅めつきはフルアディ ティブ法 ${ }^{45)}$ や図 2 のような高多層基板 ${ }^{46)}$ などに一部で使用 されている。大型コンピューター用の基板は配線層が数 10 層で板厚が $5 \mathrm{~mm}$ 以上ありスルーホールのアスペクト比は 10２5 と非常に高く，電気銅めっきでは均一電着性の悪さ からスルーホール中央部の膜厚が薄くなってしまう問題があ る。そこを無電解銅めっきのみで成膜すれば電流分布に起因 する膜厚の低下が無いので比較的均一な析出性が得られる。 これらの方法では無電解銅めっき皮膜がそのまま回路となる ので，熱衝撃に対する皮膜物性，特に高い延性が要求される。 無電解銅めつき皮膜は水素脆性の影響で電気銅めつき皮膜と 比較すると延性が劣る欠点があり，皮膜物性の向上について 多く検討されている。皮膜延性を向上するには添加剤の選定

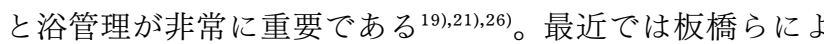
り皮膜物性が良いグリオキシル酸浴の適用や47), 添加剤がビ アホール内の均一析出性に与える影響48) について報告され ている。

5. 2. 3 ビルドアップ法

電子機器の高性能化のためにプリント配線板は常に高密度

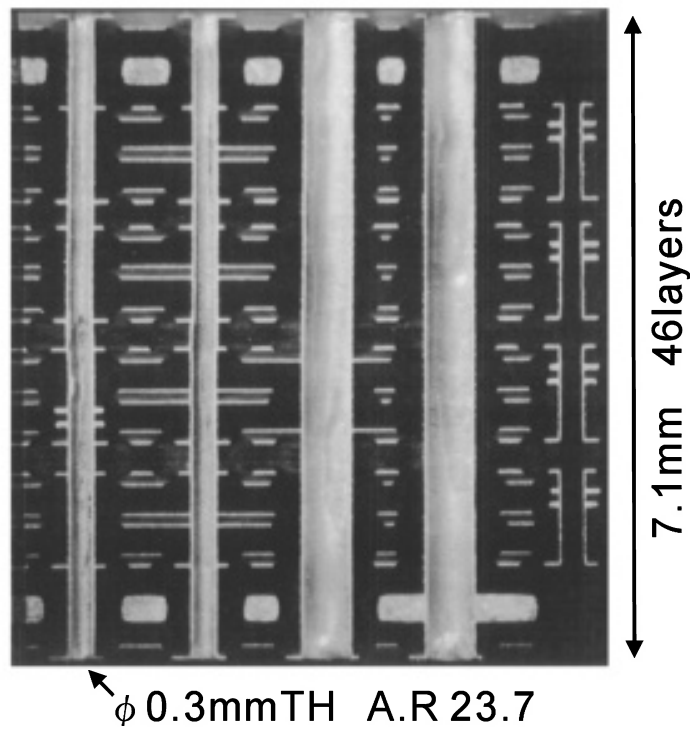

図 2 高アスペクト TH への厚付け無電解銅めっき
化が要求されており, 現在では多層板の製造法としてビルド アップ法49) が携帯電話など小型電子機器には必要不可欠な 技術となっている。この工法は回路形成された基板の上に絶 縁樹脂と銅回路層を 1 層ずつ順次積み重ねていく方法で，各 層の回路間は絶縁層へのブラインドビアホール形成と銅めつ きにより接続される。またセミアディティブ法により回路形 成することでさらに配線ピッチ間の縮小が可能となる。これ に使用する無電解銅めっきはビアホール内の付きまわりと樹 脂上の密着性が重要となる。微小径ビアホールではホール内 への銅イオンの供給が少なくなるためビアホール底部で無電 解銅めつきが薄くなり層間の接続不良が起こりやすい。その ためビアホール内に銅イオンを供給する工夫や50)，また図 3 のように安定剤の選定によりビアホール底部の付きまわりは 改善される。樹脂との密着性については, 過マンガン酸など による樹脂の化学的な粗化により密着向上が図られており, それとともに無電解銅めっき前処理の最適化や安定剤の選定 によっても密着性は改善される ${ }^{51,52) 。 ~}$

今後はさらなる配線の微細化と電気信号遅延の解消のため に，樹脂の粗化をせずに化学結合だけで平滑樹脂と銅間の密 着性を確保する技術が必要であり，図 4 のように酸化チタン 光触媒と紫外線の併用による樹脂の表面改質処理により化学 的密着を向上させる方法などが検討されている ${ }^{53), 54) 。 ~}$

\section{6. 無電解銅めっきの今後の展開}

最近の無電解銅めっきの応用例としては，環境対応のため のホルムアルデヒドフリー化と LSI の配線形成やマイクロ パターン形成などのナノテクノロジーへの応用が融合された 技術に関するものが多い。LSI の微細配線形成には，トレン

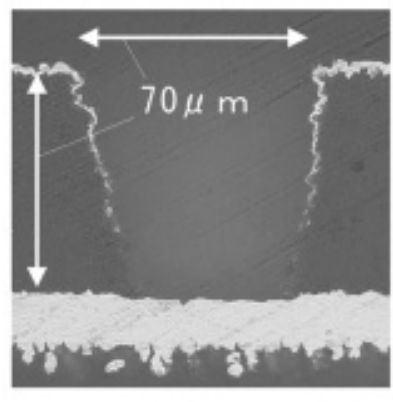

安定剂 A (接続不良)

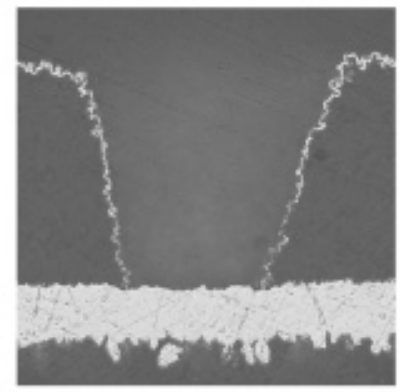

安定剂B
図 3 ブラインドビアホールへの無電解銅めっき

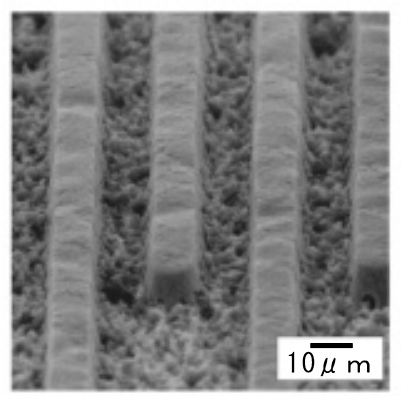

過マンガン酸粗化処理

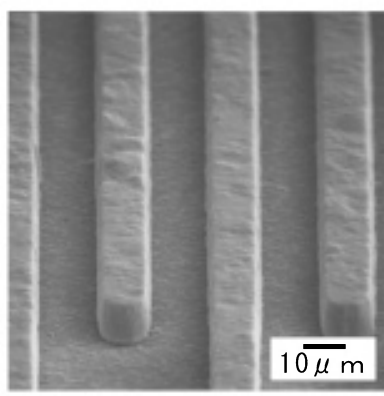

表面改質処理 


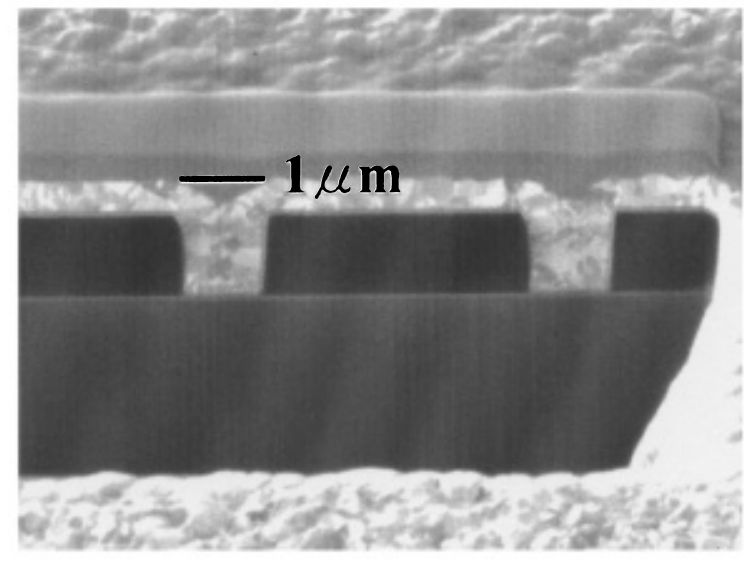

図 5 無電解銅めっきによる LSI 配線の埋め込み

チやコンタクトホールを硫酸銅めつきにより埋め込むダマシ ン法が現在主流であり，この導電層にはPVDやCVDによ る $\mathrm{Cu}$ シード層が使われているが，高アスペクト比な配線で はトレンチやホール底部での膜厚が不足しボイドが発生する 問題がある。この問題に対して Z. Wang ら ${ }^{55)}$ や川北ら ${ }^{56)}$ は, グリオキシル酸を還元剤とするナトリウムフリーの無電解銅 めつきによる埋め込みについて報告している。

ガラスやポリイミド・液晶ポリマーへの無電解銅めつきは 密着が得られにくいためこれまで困難とされてきたが, これ らは電子分野で重要な材料であり無電解銅めっきによる金属 化が盛んに研究されている。ガラスへの無電解銅めっきは藤 嶋ら ${ }^{57)}$ の方法のように酸化亜鉛膜などを中間層に用いない と全く密着が得られない。M. Izaki ら ${ }^{58), 59)}$ は化学成膜によ る酸化亜鉛膜の形成と無電解銅めつきの密着向上を報告した。 赤松ら ${ }^{60), 61)}$ はシラン系単分子膜を形成したガラスやポリイミ ド上に酸化チタン光触媒あるいはクエン酸等の還元助剤を使 用して，紫外線による銅のダイレクトパターン形成について 検討している。バインダー層を使用しないガラス上への直接 無電解銅めっきとしては齋藤ら ${ }^{62)}$ はセンシタイザー・アク チベーター法とグリオキシル酸浴を用いたガラス上への直接 無電解銅めつきについて発表しており, 久保田ら ${ }^{63)}$ も同じ 前処理法でガラス上への部品実装に耐えられる高密着な無電 解銅めっき法を確立している。液晶ポリマーへのめつきでは, 梅原 ${ }^{64)}$ らが次亜リン酸浴で密着性の向上を検討し, また福 谷 ${ }^{65)}$ らはアミノ基含有シラン化合物の薄膜パターンを形成 し無電解銅めっきの微細パターンを形成している。

縄舟らは, $\mathrm{Co}^{2+}$ を還元剤とする無電解銅めっきが中性で 水素ガス発生が無いことに着目し，アスコルビン酸やビピリ ジルを添加するなどの改良を加え, 図 5 のような LSI 配線 への埋め込み ${ }^{66)}$ やインクジェット法によるポリイミドへの ダイレクトパターン形成 ${ }^{67)}$ な゙に応用している。稗田 ${ }^{68)} ら$ は $\mathrm{Si}$ 基板表面にアミノ基含有シラン化合物の薄膜パターン を形成し無電解銅めっきで銅パターンを形成後, Nafion シート上に銅パターンを転写する方法を発表した。この技術 はナノ燃料電池の電極へ応用の可能性がある。

\section{7.おわりに}

無電解銅めつきはプリント配線板やプラスチックへのめつ
きとして工業的に発展し，さまざまな手法で解析されてきた。 今後は半導体・ナノテクノロジー分野へ応用され, さらに重 要な技術になっていくと思われるが, 皮膜のブリスター発生 の要因や密着性, 皮膜構造に関する研究例は少なく,いまだ 未知な部分も多く残されている。さらなる研究や各分野への 応用に期待したい。

(2006-11-29 受理)

\section{文献}

1) H. Narcus ; Metal Finishing, 45, (9), 64 (1947).

2) S. Wein ; Metal Finishing, 46 (8), 58 (1948).

3 ) A. E. Cahill ; Proc. Amer. Electroplaters' Soc., 44, 130 (1957).

4 ) E. B. Saubestre ; Proc. Amer. Electroplaters' Soc., 46, 294 (1959).

5 ) R. M. Lukes ; Plating, 51, 1066 (1964).

6 ) W. Goldie ; Plating, 51, 1069 (1964).

7 ）小西三郎；金属表面技術, 16, 111 (1965).

8 ）斎藤 囲；金属表面技術, 16, 300（1965）.

9 ）斎藤 囲；金属表面技術，17，258，264（1966）.

10）広幡兵伍, 老田昌弘, 本城克彦; 金属表面技術, 23, 465 （1972）.

11）大野 湶；金属表面技術, 32, 546（1981）.

12）大野 湶, 若林 理, 春山志郎; 電気化学, 53, 190 (1985).

13) M. Paunovic ; Plating, 55, 1161 (1968).

14）斎藤 囲, 本間英夫 ; 金属表面技術, 29, 403（1978）。

15）永田弘人，小岩一郎，逢坂哲彌，吉井敏文; 金属表面技術, 36, 230 (1985).

16）水本省三, 縄舟秀美, 松本邦勝, 川崎元雄, 木下朱美, 荒木 建；表面技術, 41, 912（1990）.

17）広幡兵伍, 老田昌弘, 本城克彦; 金属表面技術, 21, 550 （1970）。

18）斎藤 囲, 本間英夫；金属表面技術, 29, 88, 190 （1978）。

19）松岡政夫, 伊藤達志, 林 忠夫 ; 金属表面技術, 33, 385 （1982）.

20) M. Matsuoka and T. Hayashi ; Metal Finishing, 83, (6), 85 (1985).

21）水本省三, 縄舟秀美, 川崎元雄, 木下朱美, 荒木 建 ; 金属表面 技術, 36, 64 (1985).

22）水本省三, 縄舟秀美, 川崎元雄; 金属表面技術, 39, 301（1988）.

23) J. Li and P. A. Kohl ; Plating \& Surf. Fin., 91, (2), 40 (2004).

24）神戸徳蔵；無電解めっき, p. 7 (檳書店, 1984).

25）広幡兵伍, 老田昌弘, 本城克彦; 金属表面技術, 23, 393 （1972）.

26）本間英夫, 水嶋信也; 金属表面技術, 34, 290 （1983）.

27）豊永 実; プリント配線板のめっき技術, p. 129（槇書店, 1996).

28) F. J. Nuzzi ; Plating \& Surf. Fin., 70, (1), 51 (1983).

29) J. Darken ; Printed Circuit World Conventions V Glasgow, B 6/2 Technical paper (1990).

30）本間英夫, 小松素明, 藤波知之 ; 表面技術, 42, 913 (1991).

31）板橋武之, 赤星晴夫, 飯田 正, 高井英次, 西村尚樹 ; エレクト ロニクス実装学会誌, 5, 252 (2002).

32) A. Hung ; Plat. Surf. Finish., 75, (1), 62 (1998).

33）藤波知之, 寺島佳孝；電子材料, 31, 144 (1998).

34）藤波知之, 黄 顕程, 本間英夫; エレクトロニクス実装学会誌, 1, 66 (1998).

35) J. Li and P. A. Kohl ; J. Electrochem. Soc., 149, C 631 (2002).

36) F. Pearlstein and R. F. Weightman ; Plating, 60, 474 (1973). 
37) A. Vaskelis, E. Norkus, J. Jaciauskiene and J. Reclaitis ; Galvanotechnik, 90, 1556 (1999).

38) M. Sone, K. Kobayashi, M. Saitou and Y. Sato ; Electrochim. Acta, 49, 233 (2004).

39）友野理平；金属表面技術，16，19（1965）。

40）小西三郎；金属表面技術, 16, 111 (1965).

41）中村 実, 斎藤 囲；金属表面技術, 16, 546 (1965).

42）松永正久，萩生田善明，伊藤僖候; 金属表面技術， 19， 223 (1968).

43）岡村寿郎, 川岸重光, 神戸徳蔵, 鷹野 修; 無電解めつきの応 用, p. 83 (横書店, 1991).

44）中村憲二；表面技術, 49, 1263 (1998).

45）川本峰雄, 赤星晴夫, 吉村豊房, 山崎 宏, 石丸敏明 ; サーキッ トテクノロジ, 6, 72 (1991)

46）和嶋元世；サーキットテクノロジ, 9, 88 (1994).

47）板橋武之, 赤星晴夫, 飯田 正, 高井英次, 西村尚樹; エレクト ロニクス実装学会誌, 5, 252（2002）.

48）板橋武之, 赤星晴夫, 飯田 正; 表面技術協会第 108 回講演大 会要旨集, p. 22（2003）.

49）塚田 裕；回路実装学会誌，13，65（1998）.

50）阿部真二, 藤波知之，青野隆之，本間英夫；表面技術，48，433 (1997).

51）石橋純一, 小林 健, 市川卓美, 本間英夫 ; エレクトロニクス 実装学会誌, 1, 483 (1998).

52) S. Siau, A. Vervaet, E. Schacht and A. V. Calster ; J. Electrochem. Soc., 151, (2), C 133 (2004).

53）渡邊建治, 藤村 翼, 西脇泰二, 田代雄彦, 本間英夫 ; エレクト ロニクス実装学会誌, 7, 136（2004）.
54）別所 毅, 井上浩徳, 石川久美子, 小岩一郎, 本間英夫 ; 表面技 術, 57, 157 (2006).

55) Z. Wang, O. Yaegichi, H. Sakaue, T. Takahagi and S. Shingubara ; J. Electrochem. Soc., 151, C 781 (2004).

56）川北泉, 長谷川円, 沖中 裕, Y. Shacham-Diamand, 逢坂哲 彌；表面技術協会第 113 回講演大会要旨集, p. 178 (2006).

57）藤嶋 昭, 吉識 肇；機能材料, 14, （1），33（1994）。

58) M. Izaki and J. Katayama ; J. Electrochem. Soc., 147, (1), 210 (2000).

59）大友さとみ, 片山順一, 伊崎昌伸 ; 第 16 回マイクロエレクト ロニクスシンポジウム講演集, p. 347 (2006).

60）赤松謙祐, 池田慎吾, 縄舟秀美; 表面技術, 56, 665（2005）.

61）有村英俊, 内田 衛, 木村明寛, 赤松謙祐, 縄舟秀美; 第 16 回 マイクロエレクトロニクスシンポジウム講演集, p. 79（2006）.

62）齋藤裕一, 清田浩之, 和久田陽平, 本間英夫; 表面技術協会第 114 回講演大会要旨集, p. 99 (2006).

63）久保田浩, 鈴木邦明, 三森健一 ; 第 16 回マイクロエレクトロ ニクスシンポジウム講演集, p. 223（2006）.

64) 梅原弘次, 新保一樹, 斉藤 徹, 有泉昇次, 小早川紘一, 佐藤祐 一；エレクトロニクス実装学会誌, 7, 328 (2004).

65）福谷修平, 浅倉秀一, 不破章雄; エレクトロニクス実装学会誌, 8, 325 (2005)

66）縄舟秀美，樋口晋吾，赤松謙祐，内田 衛; 表面技術，54，683 (2003).

67）縄舟秀美; 第 15 回マイクロエレクトロニクスシンポジウム 講演集, p. 1 (2005)

68）稗田純子, 齋藤永宏, 太田理一郎, 高井 治; 表面技術, 56, 113 (2005). 